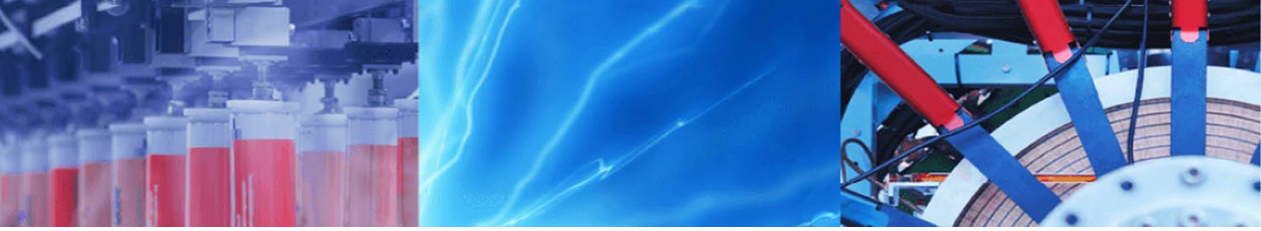

Research Article

\title{
Investigating new techniques for the treatment of oil field produced water and energy production
}

\author{
Salman Hisham ${ }^{1} \cdot$ Faizal Ayub Khan $^{1}$ - Saad A. Aljili ${ }^{2}$ Mostafa Ghasemi ${ }^{1}$
}

(c) Springer Nature Switzerland AG 2019

\begin{abstract}
In the oil and gas industry, the production of oil field produced water is a common problem, especially in ageing fields. The current solution to produce water treatment is to partially treat the produced water through chemical means. However, little effort was taken into consideration to generate electricity through the treatment process. A microbial fuel cell is a bioreactor that converts chemical energy in chemical bonds to electrical energy with the presence of microorganism acting as biocatalyst. With increasing cost of oil field produced water treatment and the raising environmental concerns of produce water disposal. Microbial fuel cells have been widely discussed as a suitable treatment method of oil field produced water as well as a method for generating power through electricity generation. This paper discusses the ability of microbial fuel cell in treating by the removal of chemical oxygen demand and generating electricity from untreated and partially treated oil field produced water. The various pre-treatment methods provide different environments to study the effectiveness of the microbial fuel cell in treating the produced water and generating electricity. In conclusion, microbial fuel cells are capable of treating oil field produced water while generating electricity. At the end of the experiment, it was found that partial treatment that preserves the oil and grease content of the produced water proved to give the best balance between treatment capability of microbial fuel cell and the electricity generated.
\end{abstract}

Keywords Microbial fuel cell $\cdot$ Renewable energy $\cdot$ Water treatment $\cdot$ Oil field produced water

\section{Introduction}

Energy is a basic and fundamental requirement for economic and social activities. The global demand for energy consumption increased exponentially, especially in developing countries [1]. The major sources of energy currently used are sourced from oil, gas and other forms of fossil fuels. By the year 2030, world's daily consumption of oil is estimated to be 106 million barrels [2]. However, oil and gas production also produces highly saline water.

Produced water can be defined as water trapped in underground formation that is brought to the surface along with oil or gas [3]. Produced water has complex composition. Generally, components of produced water can be classified into organic and inorganic matter including oil particles, grease, heavy metals, radionuclides, salts, microorganism and dissolved oxygen and gasses [2]. Treated produced water can also be used for drilling and workover operation within the upstream oil and gas industry $[4,2]$.

MFC is defined as a bioreactor that converts chemical energy in the chemical bonds in organic compounds to electrical energy through catalytic reactions of microorganism under anaerobic conditions [5]. This is different to bioremediation which is defined as the conversion of chemical toxic and simple organic compound to water and carbon dioxide through aerobic condition [6]. In an MFC, microorganisms are placed in the anode chamber in an anaerobic condition. The microorganism oxidizes the

\footnotetext{
$\triangle$ Mostafa Ghasemi, mostafa.baboli@utp.edu.my| ${ }^{1}$ Department of Petroleum Engineering, Universiti Teknologi PETRONAS, Bandar Seri Iskandar, Perak, Malaysia. ${ }^{2}$ National Centre for Water Treatment and Desalination Technology, King Abdulaziz City for Science and Technology, Riyadh, Saudi Arabia.
} 
organic compounds in the produced water to hydrogen and carbon dioxide. The hydrogen then passes through a proton exchange membrane (PEM) to the cathode where it is reduced by reacting with oxygen molecules to form water. This creates electricity flow from the two terminals through a resistor $[5,7,8]$.

Efficiency of MFC is highly dependent on several criteria. In the past few years, studies have been conducted on the viability of biological treatment of oilfield produced water. One of the major issues of treating the produced water is the selection of proper bacteria that survives in harsh environment such as produced water. In an MFC, the selected microorganism must be able to survive in hypersaline environment and has exoelectrogenic capabilities [4].

The outer portion of majority of the microbial species is made up of non-conductive lipid layers that prevent electron transfer directly to the anode. This requires an electron mediator such as neutral red or methylene blue to accelerate the electron transfer rate [5]. The best mediator can be identified for achieving high-performance MFC on the basis of redox potential difference [9]. However, researches also have shown respiratory enzymes of ironreducing bacteria can allow direct transfer of electron to the anode without the need for an electron mediator [10].

Produced water commonly contains high amount of salt, where $250 \mathrm{~g} / \mathrm{L}$ of $\mathrm{NaCl}$ in produced water is common. High concentration of salt creates osmotic stress and plasmolysis in bacterial cell [5]. Based on previous studies, bacteria from genuses Pseudomonas, Marinobacter, Aeromonas, Bacillus, Ochrobactrum, Achromobacter and Rhodococcus proved to be efficient in removing organic compounds from wastewater as they synthesize bio-emulsifiers that enhance bioavailability of the hydrocarbon [11].

There are various designs and configurations used in MFCs. However, MFC can be classified to batch fed and continuous flow. There are several designs for the MFC cathode which are air-breathing, water-submerged and photosynthetic microorganism [12]. The MFC configuration dictates the oxygen availability at the cathode which in turns affects the efficiency and effectiveness of the MFC. Researchers also found that forced air flow through cathode reduced power generation compared to passive flow. This is due to significant loss of chemical oxygen demand (COD) due to transport of oxygen across the PEM [10]. In water-submerged cathode MFC, rate of oxygen consumption is generally higher than the oxygen diffusion rate from the atmosphere into the water [12].

Common PEMs used in MCFs are Nafion and CMI$7000 S$ [1]. The PEM is required to be pre-treated to remove the organic particles that may be present during the manufacturing process. An optimum temperature and pressure are vital in having maximum electricity generation and COD removal. Research has shown degradation of crude oil is best at $\mathrm{pH} 7$ and $35^{\circ} \mathrm{C}$ for Enterobacter Cloacae [6]. However, past research also proved that $\mathrm{pH} 6.5$ and ambient temperature could also return similar COD removal efficiency [13].

The MFC needs to exceed the internal resistance in order to produce electricity. A high electron transfer rate from the anode to cathode leads to high electricity generation. Based on previous researches, when the external resistance was increased from 1 to $15 \mathrm{k} \Omega$, there is a sudden drop in current density produced in the MFC [14].

It is beneficial to use combination of pre-treated process than a single method of produced water treatment [15]. Coagulation-flocculation is commonly used in treating wastewater. This process can be divided into two distinct processes which should be done consecutively. Coagulation is a process where colloidal suspension or solution is destabilized using chemicals called destabilizing agents such as salts of aluminium or iron [16]. Colloidal particles naturally carry charges on their surface, adding these chemicals surface property of colloidal particle can be changed and be precipitated [17]. Using alum as a coagulant, the COD removal of coagulation-flocculation was reported to be $61 \%$ [16].

Forward osmosis is a membrane process in which no hydrostatic pressure is applied. The working principle of forward osmosis is by transport of water molecules through semipermeable membrane due to the osmotic pressure across either side of the membrane [18]. The COD removal efficiency was reported to be around $71 \%$. However, forward osmosis was reported to have an organic carbon removal of 99\% [19]. However, in higher salinity samples, pre-treatment through osmosis returns a higher current density in microbial fuel cell [20]. Reverse osmosis is also another method commonly used in wastewater treatment. The COD removal efficiency using reverse osmosis was reported to be $90 \%$ [21].

The scope of this paper is to investigate new method of treating oil field produced water and pre-treated oilfield produced water undergone microfiltration, coagulation-flocculation, forward osmosis and reverse osmosis using MFCs. The effectiveness of this is measured by determining the COD before and after the water treatment process.

Besides that, this study is also conducted to investigate the effectiveness and efficiency of the MFC to generate power through the production of electricity. Effectiveness of the MFC will be measured and described by the current density and power density of the MFC. 


\section{Materials}

Sample of oilfield produced water from Malays Basin was obtained from Petronas Carigali. The sample was at separator from Angsi field located at offshore Terengganu, Malaysia. Samples of produced water from Angsi field undergone microfiltration, coagulation-flocculation, forward and reverse osmosis were obtained. Before the experiment was conducted, the initial COD of the sample was measured with a spectrophotometer. The initial values of COD were recorded. Methylene blue solution was prepared as an electron carrier. Figure 1 illustrates the produced water dated 7 July 2018.

\section{Apparatus and procedure}

\subsection{Preparation and assembly of MFC}

The microbial fuel cell is assembled in two sections, namely the cathode and the anode chambers. The main material used in the fabrication of these chambers is a $0.5-\mathrm{cm}$ clear Perspex. Each chamber was glued together with slow-setting epoxy adhesive (Araldite). A total of eight holes were milled for the placement of 4-mm bolt as a clamping mechanism between the anode and cathode chambers. Each chamber has a dimension of $6 \mathrm{~cm} \times 6 \mathrm{~cm} \times 6 \mathrm{~cm}$ giving a total volume of $216 \mathrm{~cm}^{3}$. A silicon gasket was used as leak between the cathode and anode chambers.

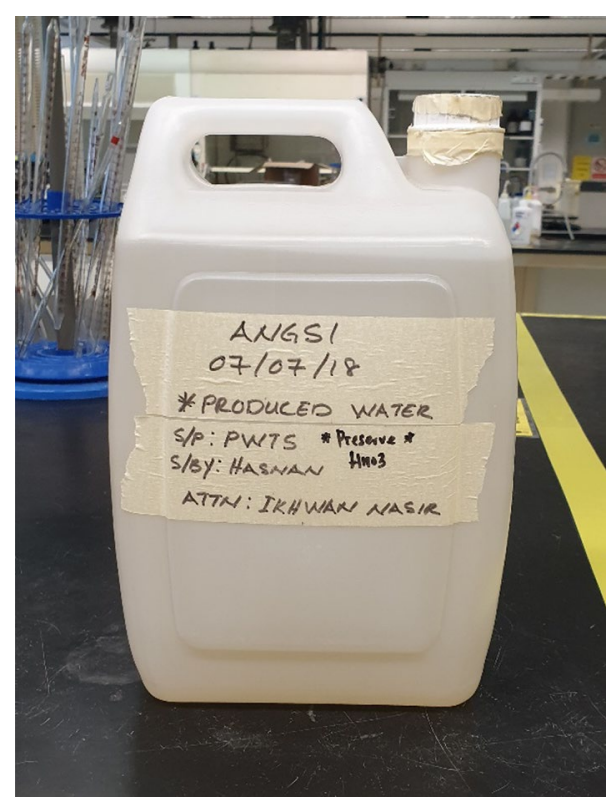

Fig. 1 Produced water sample from Angsi field
Further leakage prevention is done using silicon clear sealant (Fig. 2).

\subsection{Preparation of PEM}

The PEM selected for this experiment was CMI-7000S. The PEM was prepared by initially boiling the membrane in distilled water as displayed in Fig. 3. Then, the membrane was boiled in 3\% hydrogen peroxide solution. The membrane was then further washed with deionized water. $0.5 \mathrm{M}$ of sulphuric acid was used to wash the membrane. Lastly, the membrane was again washed with deionized water. The prepared PEM was stored in distilled water to maintain the membrane for excellent conductivity [22-26]. Based on the previous research, this method of pre-treatment gives the best organic impurities removal after the manufacturing process of the membrane.

\subsection{Conducting experiment}

The sample for microfiltration was conducted using a cellulose membrane with pore size of $0.45 \mu \mathrm{m}$. The coagulation and flocculation was conducted with sulphuric acid for the acidification stage and alum as the coagulant [27]. The samples prepared were labelled as follows:

Sample 1: Produced water

Sample 2: Produced water treated by microfiltration

Sample 3: Produced water treated by coagulation-flocculation

Sample 4: Produced water treated by forward osmosis

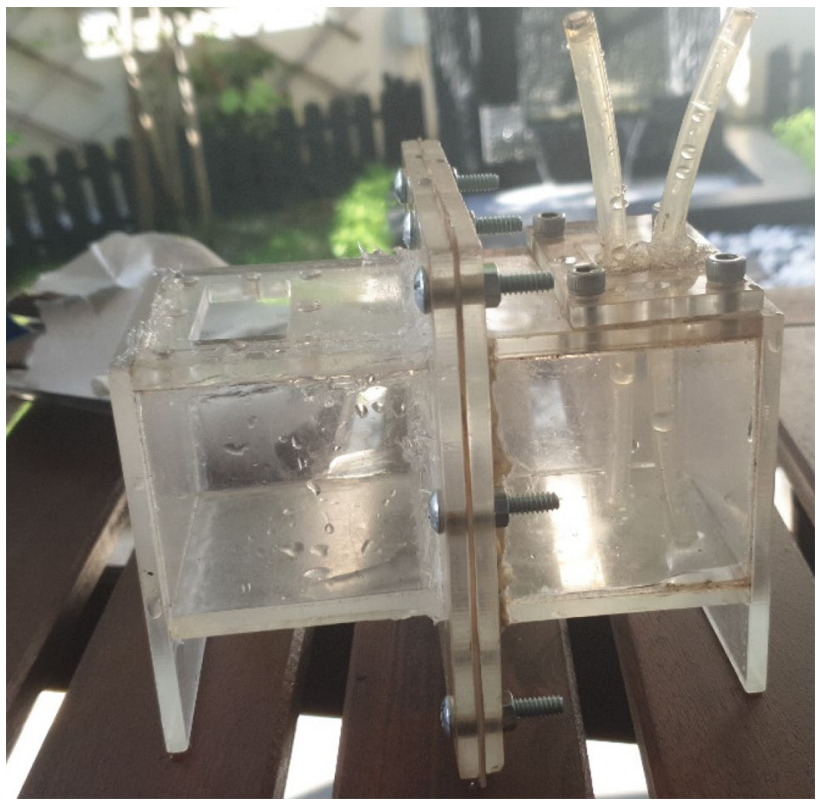

Fig. 2 Assembled MFC 


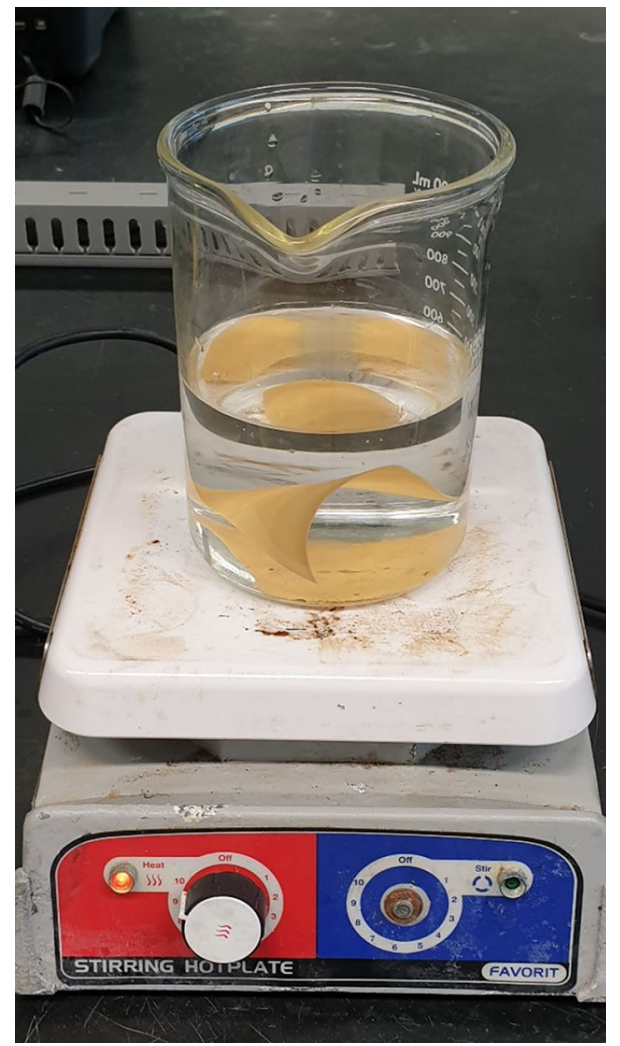

Fig. 3 Pre-treatment of PEM

Sample 5: Produced water treated by reverse osmosis.

The anode and cathode were connected through a $1000 \Omega$ resistor as a load to the system [25, 14] (Fig. 4). Samples were placed in the anodic chamber of the MFC, while distilled water was added in the cathode chamber up to $4 \mathrm{~cm}$ of height in each chamber. Therefore, the volume of water in each chamber is $144 \mathrm{~cm}^{2}$. Three drops of methylene blue were added into the anodic chamber. Figure 5 illustrates the setup of the microbial fuel cell as well as the multi-meter setup for voltage measurement. The mixtures were allowed to settle for $15 \mathrm{~min}$ in the anodic chamber before the first reading at time $=0$ was taken. The area electrode in contact with water level is given at $0.001256637 \mathrm{~m}^{2}$.

\subsection{Measurement of voltage and current density}

The current flow between the terminal electrodes was measured with a multi-meter every $30 \mathrm{~min}$ for $7 \mathrm{~h}$ [22]. The values were the plotted and the current density was calculated using the following formula [28]:

Current Density $=\frac{\text { Voltage }_{\text {MFC }}}{\text { Area }_{\text {Electrodee }}\left(\text { Resistance }_{\text {Resistor }}\right)}$.

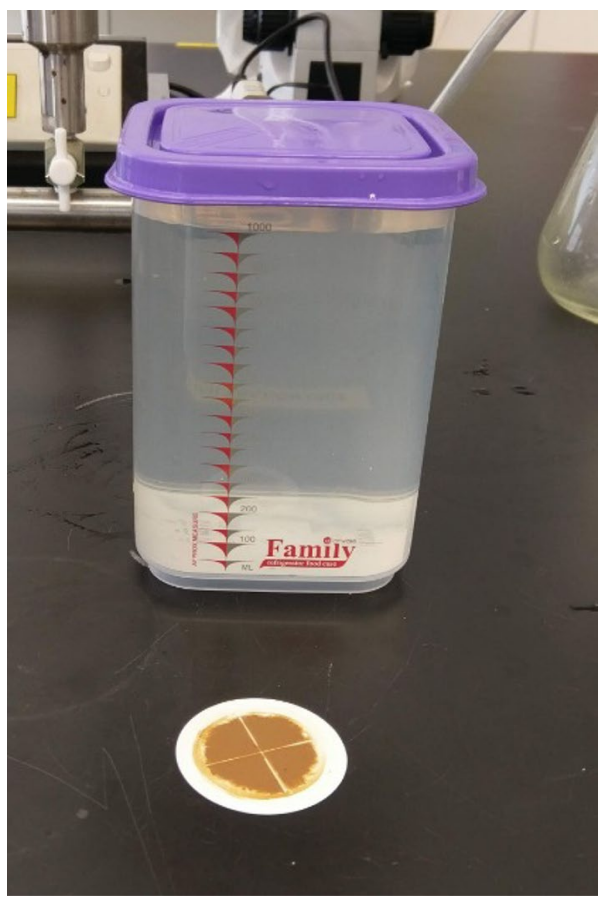

Fig. 4 Sample of produced water undergone microfiltration

The COD of the treated produced water sample was measured using a spectrophotometer after a day. The COD removal efficiency was calculated by using the following formula [29]:

Percentage $C O D$ Removal $=\frac{C O D_{\text {initial }}-C D_{\text {final }}}{C O D_{\text {initial }}} \times 100 \%$.

In order to measure the COD of the samples, highrange COD reagents (Hanna HI93754B-0) were used in measuring the COD. Before measuring the $C O D$, a blank vial should be prepared. Two millilitres of distilled water

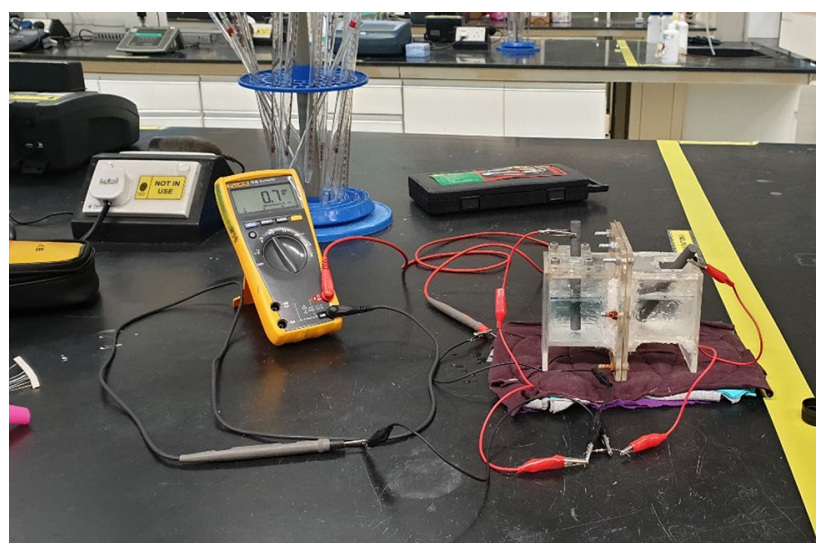

Fig. 5 Set-up of MFC and voltage measurements 
will be added into the vial and would be used to recalibrate the spectrophotometer (HACH DR3900).

\section{Results and discussion}

\subsection{Electricity and energy generation}

Based on Fig. 6, sample 1 has the highest maximum current density of $10.35 \mathrm{~mA} / \mathrm{m}^{2}$ among the three samples. The trend can be explained as untreated produced water contains the maximum organic compound in which the microorganism was able to break down anaerobically. The maximum current density was at the 5 th hour. Besides that, the untreated produced water also contains various microorganisms that were able to survive in the highly saline, acidic oxygen-lacking environment (Table 1).

However, the current density was lower in Sample 2. Sample 2 was prepared by microfiltration using a filter with a pore size of $0.45 \mu \mathrm{m}$. The pore size filters out the pre-existing bacteria in the pure produced water sample, hence reducing the bacterial presence and therefore the effectiveness of the microbial fuel cell in breaking down the organic compound in the sample. An average microorganism has a size of 10 microns. The maximum current density generated was $0.32 \mathrm{~mA} / \mathrm{m}^{2}$ at the 1.5 th hour. Since the $\mathrm{pH}$ will not change during microfiltration. Low $\mathrm{pH}$ value will retard the metabolic rate of the microorganism in the microbial fuel cell.

Sample 3 gives a maximum current density of $1.99 \mathrm{~mA} / \mathrm{m}^{2}$ at $4.5 \mathrm{~h}$. This can be explained since the coagulation-flocculation reduces the total organic content in the produced water. Therefore, the organic content for the microorganism to break down will be reduced significantly. However, during coagulation-flocculation, the $\mathrm{pH}$ will be adjusted to $\mathrm{pH} 7$; therefore, the
Table 1 Current density for various samples

\begin{tabular}{llllll}
\hline Time (h) & \multicolumn{5}{l}{ Current density $\left(\mathrm{mA} / \mathrm{m}^{2}\right)$} \\
\cline { 2 - 6 } & Sample 1 & Sample 2 & Sample 3 & Sample 4 & Sample 5 \\
\hline 0 & 0.00 & 0.00 & 0.00 & 0.00 & 0.00 \\
0.5 & 0.16 & 0.16 & 0.24 & 0.00 & 0.00 \\
1 & 0.40 & 0.24 & 0.40 & 0.00 & 0.00 \\
1.5 & 1.59 & 0.32 & 0.40 & 0.00 & 0.08 \\
2 & 3.98 & 0.24 & 0.95 & 0.00 & 0.08 \\
2.5 & 3.98 & 0.16 & 0.95 & 0.00 & 0.08 \\
3 & 5.97 & 0.16 & 1.03 & 0.00 & 0.08 \\
3.5 & 7.96 & 0.16 & 1.19 & 0.00 & 0.08 \\
4 & 9.55 & 0.16 & 1.67 & 0.00 & 0.08 \\
4.5 & 9.55 & 0.16 & 1.99 & 0.00 & 0.00 \\
5 & 10.35 & 0.16 & 1.83 & 0.00 & 0.00 \\
5.5 & 9.55 & 0.08 & 1.19 & 0.00 & 0.00 \\
6 & 9.55 & 0.08 & 1.03 & 0.00 & 0.00 \\
6.5 & 9.55 & 0.08 & 0.48 & 0.00 & 0.00 \\
7 & 7.96 & 0.08 & 0.32 & 0.00 & 0.00 \\
\hline
\end{tabular}

metabolic rate of microorganism will be at an optimum rate.

The current density was effectively 0 in Sample 4 and $0.08 \mathrm{~mA} / \mathrm{m}^{2}$ in Sample 5. Regardless of the sample having an optimum $\mathrm{pH}$ of 7.64 in both samples, the pre-treatment removes the hydrocarbon and bacterial content in the produced water. The semipermeable membrane used in the forward osmosis only allows the migration of water from the lower salinity produced water to the higher salinity draw solution. However, the hydrocarbon removal efficiency in reverse osmosis is lower compared to forward osmosis, hence leading to the difference in the current density between Sample 4 and Sample 5 (Fig. 7).
Fig. 6 Graph of current density against time

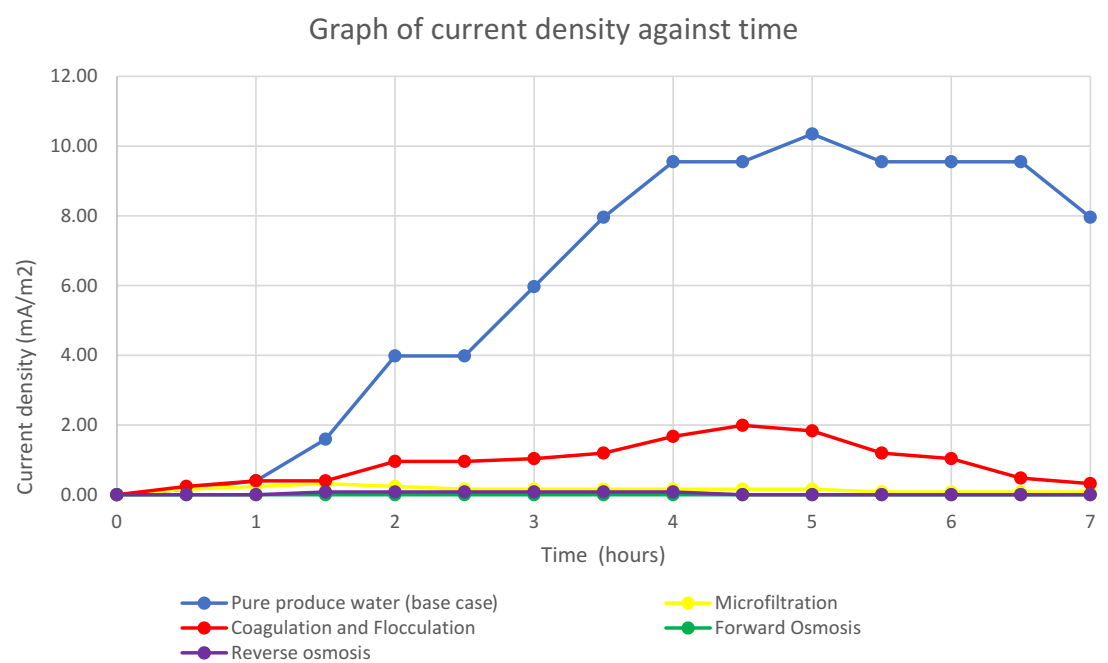

SN Applied Sciences 


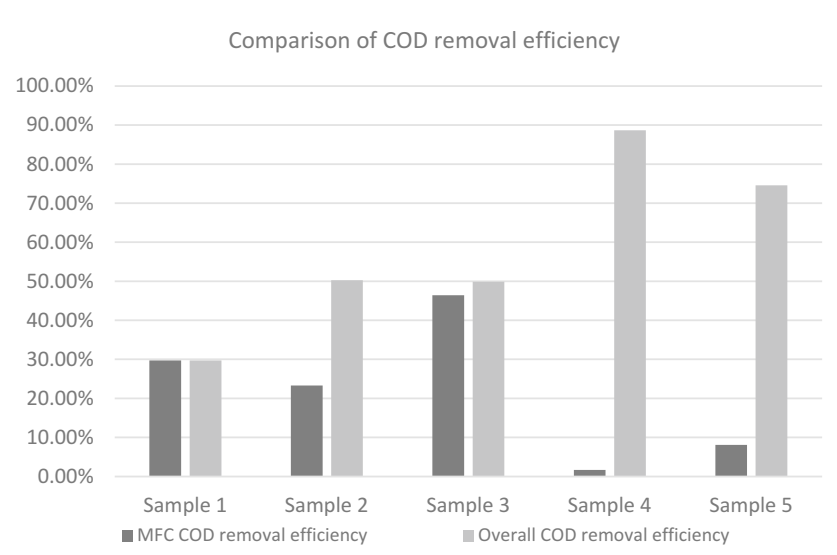

Fig. 7 Comparison of COD removal efficiency for various samples

\subsection{COD removal efficiency}

In Sample 1, where no pre-treatment was conducted, the COD removal efficiency of the MFC is $29.72 \%$. This sample had an initial oil and grease content of $6.6 \mathrm{ppm}$. The difference in COD removal efficiency of previous experiment of $68 \%$ can be explained by the low $\mathrm{pH}$ value that reduces the bacterial removal efficiency, hence reducing its COD removal efficiency. The final COD by treating the produced water is at $3956 \mathrm{mg} / \mathrm{l}$ (Table 2).

Sample 2 was pre-treated through microfiltration. The MFC COD removal efficiency was at $23.31 \%$. These samples had a post-microfiltration oil and grease content of $3.25 \mathrm{ppm}$. The lower COD removal efficiency using the MFC can be explained, since microfiltration removes the bacterial presence as well as the low $\mathrm{pH}$ in the sample. However, the overall COD removal efficiency using MFC as well as microfiltration was $50.26 \%$. This is mainly because the microfiltration process using $0.45-\mu \mathrm{m}$ filter paper removes large amount of hydrocarbon presence in the sample. This is evident as the grease and oil content has reduced from 6.6 to $3.25 \mathrm{ppm}$.

Sample 3 was pre-treated using the coagulation and flocculation method with an MFC COD removal efficiency of $46.42 \%$. The oil and grease content after the pre-treatment method was at $3.75 \mathrm{ppm}$. This trend is mainly due to the neutral $\mathrm{pH}$ nature of the sample. Coagulation and flocculation pre-treatment adjusted the $\mathrm{pH}$ of the sample to a pH of 7. Besides that, coagulation-flocculation methods preserve the hydrocarbon content of the sample. As the sample still contains relatively high hydrocarbon content. The bacterial metabolism can break down the hydrocarbon, reducing the COD. This trend can also be seen in the maximum current density higher than Sample 2 . The overall COD removal efficiency of this system was $49.87 \%$.

Sample 4 and sample 5 were pre-treated using forward osmosis and reverse osmosis methods, respectively. The COD removal efficiency was relatively low at $1.69 \%$ and $8.09 \%$. However, the final product has the highest COD removal of $75 \%-90 \%$. This trend is mainly because of the ability of forward and reverse osmosis to remove large amounts of hydrocarbon traces in the samples. This is from the relative oil and grease content in sample 4 and sample 5 . The oil and grease contents were reported to be $0.63 \mathrm{ppm}$ and $1.52 \mathrm{ppm}$, respectively.

\subsection{Fourier transform infrared spectroscopy (FTIR) of PEM}

FTIR (Perkin Elmer) was conducted on the new and after post-MFC PEM. Based on Fig. 8, both the PEMs have peaks at wavelength $1100-1200 \mathrm{~cm}^{-1}$. This wavelength shows a strong $\mathrm{S}=\mathrm{O}$ functional group in the form of sulphonic acid. The presence of this group shows the ability of the PEM in proton exchange [24, 30]. However, the transmittance of the post-MFC PEM is lower compared to the new PEM. This further proves the effectiveness of the pre-treatment conducted on the PEM.

The peak at bands of $1400 \mathrm{~cm}^{-1}$ shows a strong $\mathrm{S}=\mathrm{O}$ stretching indicating sulphate group. The group is indicative of high proton conductivity of the PEM in low humidity [31]. Since trend contrasts with the new PEM, one can conclude that the PEM treatment using sulphuric acid of $0.5 \mathrm{M}$ is successful in enhancing the proton conductivity of the PEM.

The post-treatment PEM has high peaks at band of $800 \mathrm{~cm}^{-1}$ to $900 \mathrm{~cm}^{-1}$. This shows the presence of strong $\mathrm{C}-\mathrm{H}$ group. The strong peaks at bands around wavelengths
Table 2 COD removal efficiency of MFC

\begin{tabular}{llllll}
\hline Sample & $\begin{array}{l}\text { COD of pro- } \\
\text { duced water } \\
(\mathrm{mg} / \mathrm{l})\end{array}$ & $\begin{array}{l}\text { COD of pre- } \\
\text { treated water } \\
(\mathrm{mg} / \mathrm{l})\end{array}$ & Final COD $(\mathrm{mg} / \mathrm{l})$ & $\begin{array}{l}\text { MFC COD } \\
\text { removal effi- } \\
\text { ciency }(\%)\end{array}$ & $\begin{array}{l}\text { Overall COD } \\
\text { removal effi- } \\
\text { ciency (\%) }\end{array}$ \\
\hline Sample 1 & 5629 & - & 3956 & 29.72 & 29.72 \\
Sample 2 & 5629 & 3651 & 2800 & 23.31 & 50.26 \\
Sample 3 & 5629 & 5267 & 2822 & 46.42 & 49.87 \\
Sample 4 & 5629 & 650 & 639 & 1.69 & 88.65 \\
Sample 5 & 5629 & 1558 & 1432 & 8.09 & 74.56 \\
\hline
\end{tabular}


Fig. 8 FTIR reading of PEM

FTIR Reading of PEMs

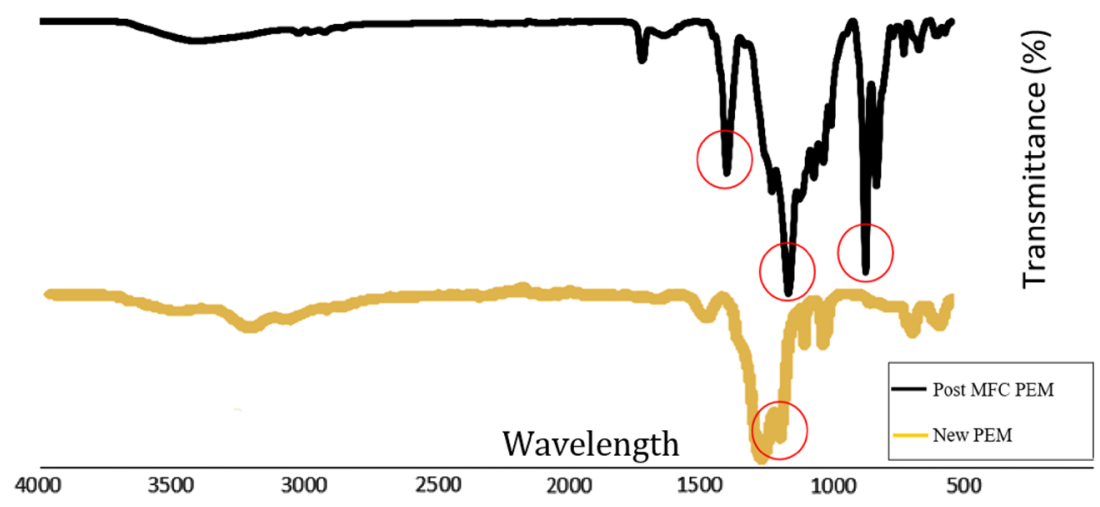

of $700 \mathrm{~cm}^{-1}$ and $900 \mathrm{~cm}^{-1}$ can be attributed to the presence of bacterial cells and biofouling traces on the posttreatment membrane [32]. This proves the presence of bacteria on the membrane surfaces.

\section{Conclusion}

As a conclusion, MFC has a viable option in treating wastewater and energy production. In treating oil and gas field produced water, pre-treatment of produced water is the best solution. Based on the experiments conducted, produced water with coagulation-flocculation gives the best balance between the maximum current density and COD removal efficiency.

By employing pre-treatment method of coagulation and flocculation, MFC was able to generate a maximum current density of $1.99 \mathrm{~mA} / \mathrm{m}^{2}$. The overall COD removal efficiency was $49.87 \%$. While sample 4 gave the highest COD removal of $88.65 \%$, the current density was very low.

Samples with neutral $\mathrm{pH}$ and high initial oil and grease content proved to have higher current densities.

\section{Compliance with ethical standards}

Conflict of interest The authors declare that they have no conflict of interest.

\section{References}

1. Flimban SG, Hassan SH, Rahman MM, Oh S-E (2017) The effect of Nafion membrane fouling on the power generation of a microbial fuel cell. Int J Hydrogen Energy. https://doi.org/10.1016/j. ijhydene.2018.02.097

2. Igunnu ET, Chen GZ (2012) Produced water treatment technologies. Int J Low Carbon Technol 9(3):157-177
3. Veil J, Purder M, Elcock D, Redweik Jr R (2004) A white paper describing produced water from production of crude oil, natural gas and coal bed methane, $\mathrm{p} 79$

4. Monzon O, Yang Y, Kim J, Heldenbrand A, Li Q, Alvarez PJJ (2016) Microbial fuel cell fed by Barnett Shale produced water: power production by hypersaline autochthonous bacteria and coupling to a desalination unit. Biochem Eng J 117:87-91

5. Du Z, Li H, Gu T (2007) A state of the art review on microbial fuel cells: a promising technology for wastewater treatment and bioenergy. Biotechnol Adv 25:464-482

6. Ahmed AW, Alzubaidi FS, Hamza SJ (2014) Biodegradation of crude oil in contaminated water by local isolates of Enterobacter cloacae 55:1025-1033

7. Jafary T, Wan Daud WR, Ghasemi M, Abu Bakar MH, Sedighi M, Kim BH, Camrmona-Martinez AA, Md Jahim J, Ismail M (2018) Clean hydrogen production in a full biological microbial electrolysis cell. Int J Hydrogen Energy. https://doi.org/10.1016/j. ijhydene.2018.01.010

8. Logan BG, Call D, Cheng S, Hamelers HV, Sleutels TH, Jeremiasse AW, Rozendal RA (2008) Microbial electrolysis cells for high yield hydrogen gas production from organic waste. Environ Sci Technol 42:8630-8640

9. Saha R, Suresh S, Park W, Lee D-Y, Karimi IA (2007) Strain improvement and mediator selection for microbial fuel cell by genome scale in silico model. In: European symposium on computer aided process engineering, pp 1-6

10. Liu H, Ramnarayanan R, Logan BE (2004) Production of electricity during wastewater treatment using a single chamber microbial fuel cell. J Environ Technol 38:2281-2285

11. Kardena E, Hidayat S, Nora S, Helmy Q (2017) Biological treatment of synthetic oilfield-produced water in activated sludge using a consortium of endogenous bacteria isolated from tropical area. J Pet Environ Biotechnol 8(3):1-6

12. Rago L, Cristiani P, Villa F, Zecchin S, Colombo A, Cavalca L, Schievano A (2017) Influences of dissolved oxygen concentration on bicathodic microbial communities in microbial fuel cells. Bioelectrochemistry 116:39-51

13. Rahimnejad M, Najafpour G, Ghoreyshi A, Shakeri M, Zare H (2011) Methylene blue as electron promoters in microbial fuel cell. Intern J Hydrog Energy 36:13335-13341

14. Kamau J, Mbui D, Mwaniki J, Mwaura F, Kamau G (2017) Microbial fuel cells: influences of external resistors on power, current and power density. J Thermodyn Catal 8(1):2-5

15. El-Naas MH, Abu Alhaija M, Al-Zuhair S (2014) Evaluation of a three-step process for the treatment of petroleum refinery wastewater. J Environ Chem Eng 2:56-62 
16. Tzoupanos ND, Zouboulis Al (2008) Coagulation-flocculation processes in water/wastewater treatment: the application of new generation of chemical reagents. Int Conf Heat Transf Thermal Eng Environ 6(1):309-317

17. Tripathy $T$, De BR (2006) Flocculation: a new way to treat the waste water. J Phys Sci 10(1):93-127

18. Korenak J, Basu S, Balakrishnan M, Helix-Nielsen C, Petrinic I (2016) Forward osmosis in wastewater treatment processes. Acta Chim Slov 64(1):83-94

19. Xiwang Z, Zhiyao N, David KW, Diniz da Costa JC (2014) Processing municipal wastewater by forward osmosis using CTA membrane. J Membr Sci 468:269-275

20. Zhang F, Brastad KS, He Z (2011) Integrating forward osmosis into microbial fuel cells for the wastewater treatment, water extraction and bielectricity generation. Environ Sci Technol 45(1):6690-6696

21. Imre PM, Mizsey P, Csefalvay E (2008) Applicability of nanofiltration and reverse osmosis for the treatment of wastewater of different origin. Central Eur J Chem 6(2):277-283

22. Rahimnejad M, Ghoreyshi AA, Najafpour G, Jafary T (2011) Power generation from organic substrate in batch and continuous flow microbial fuel cell operations. Appl Energy 88:3999-4004

23. Napoli L, Franco JI, Lavorante MJ, Sanguinetti A (2013) Effects on Nafion@117 membrane using different strong acids in various concentrations. Escuela Superior Técnica del Ejército 16:1-12

24. Ghasemi $M$, Wan Daud WR, Ismail $M$, Rahimnejad $M$, Ismail $A F$, Leong JX, Miskan M, Liau KB (2013) Effect of pre-treatment and biofouling of proton exchange membrane on microbial fuel cell performance. Int J Hydrog Energy 38:5480-5484

25. Sang-Eun O, Logan BE (2006) Proton exchange membrane and electrode surface area as factors that effects power generation in microbial fuel cell. Appl Microb Biotechnol 70:162-169

26. Rahimnejad $M$, Ghasemi $M$, Najafpour $G$, Ismail M, Mohammad A, Ghoreyshi A, Hassan SH (2012) Synthesis, characterization and application studies of self-made Fe3O4/PES nanocomposite membranes in microbial fuel cell. Electrochimca Acta 85:700-706

27. Khan FA, Hisham S, Ghasemi M (2019) Oil field produced water recovery and boosting the quality for using in membrane less cell. SN Appl Sci 1(510):1-8

28. Teleken J, de Sa Silva J, Fraga M, Ogrodowski C, Santana F, Carciofi B (2017) Mathematical modelling of the electric current generation in a microbial fuel cell inoculated with marine sediments. Braz J Chem Eng 34:211-225

29. Nwaigwe KH, Enweremadu CC (2015) Analysis of chemical oxygen demand (COD) removal rate using upflow bioreactor with central substrate dispenser (UBSCD). In: ICAESAM'2015, Kuala Lumpur

30. Hua D, Rong G, Cuihua L, Jianhong L (2007) Development and characterization of sulfonated poly(ether sulfone) for proton exchange membrane materials. Solid State Ionics 178(1):339-345

31. Raman KS, Keiji K, Kenji M, Takao T (2016) Experimental and theoretical infrared spectroscopic study on hydrated Nafion membrane. Macromolecules 49(1):6621-6629

32. Madihah M, Manal I, Mostafa G, Jamaliah MJ, Darman N, Mimi Hani AB (2016) Characterization of membrane biofouling and its effect on the performance of microbial fuel cell. Int J Hydrog Energy 41(1):543-552

Publisher's Note Springer Nature remains neutral with regard to jurisdictional claims in published maps and institutional affiliations. 